\title{
INFLUENCE OF SOIL AND WEATHER FACTORS ON THE GERMINATION OF DRY SOWN RAIN-FED CROPS ON THE SEMI ARID TRACTS OF TAMIL NADU, INDIA
}

\author{
VIJAYAPRABHAKAR, A. ${ }^{1 *}$ - VIJAYAKUMAR, E. ${ }^{2}-$ SRIDEVI KRISHNAVENI, T.R. ${ }^{1}-$ JAYANTHI, C. $^{3}$ \\ ${ }^{1}$ Institute of Agriculture, Tamil Nadu Agricultural University, Kumulur, Tiruchirappalli 621712, \\ Tamil Nadu, India \\ ${ }^{2}$ Department of Genetics and Plant Breeding, Tamil Nadu Agricultural University, Coimbatore \\ 641003, Tamil Nadu, India \\ ${ }^{3}$ Department of Agronomy, Tamil Nadu Agricultural University, Coimbatore 641003, Tamil \\ Nadu, India \\ *Corresponding author \\ e-mail: a.vijayp@ymail.com; phone: +91-959-767-2655
}

(Received $10^{\text {th }}$ Oct 2020; accepted $19^{\text {th }}$ Jan 2021)

\begin{abstract}
In rain-fed farming, crop failure and the low stands are the common problem due to poor germination of dry sown crops due to insufficient soil moisture. This leads to heavy losses of inputs, energy and time of the farmers. To address this, an investigation was made on the germination of major dry land pulses, oil seeds and fiber crops over three different locations of Northern Tamil Nadu, India during 2016-17 and 2017-18 growing periods with the objective of assessing the germination behavior of dry sown rain-fed crops to reduce germination failure. The experiment with test crops $\left(\mathrm{C}_{1}\right.$ : Blackgram, $\mathrm{C}_{2}$ : Greengram, $\mathrm{C}_{3}$ : Cowpea, $\mathrm{C}_{4}$ : Groundnut, $\mathrm{C}_{5}$ : Sesame, $\mathrm{C}_{6}$ : Cotton, $\mathrm{C}_{7}$ : Redgram) was laid out in randomized block design and observations were made on germination. According to the results, germination of sesame was higher under deficit rainfall and in saline soils with negative and positive correlations exhibiting soil moisture and soil salinity, respectively. The germination of groundnut and pulses showed poor germination under deficit soil moisture condition indicating positive correlation with soil moisture. Over different locations, sesame, cotton and cowpea gave higher mean germination under favorable condition. Raising sesame, cotton and cowpea as alternate crops or including as essential component in cropping system helps to overcome the germination failure in the study area of Northern Tamil Nadu.
\end{abstract}

Keywords: crop failure, alternative crops, dry seeding, soil moisture, salinity

\section{Introduction}

Seed germination is the most important stage and a complex process of plant's lifecycle (Bewley et al., 2013). This is a more vulnerable stage than any other stages of crop growth and development (Villalobos et al., 2016). Germination of seeds is highly essential for achieving a successful crop establishment, especially under dry land condition, since it determines the crop stand and consequently yield (Heikal et al., 1982). The poor or failure in germination is frequently occurring under field level, which leads heavy economic losses to the farmers by re-sowing. The total economic impact in monetary terms and the overall area reseeded for major crops on national and global level remain unknown (Lamichhane et al., 2018).

In rain-fed agriculture, uncertainty in rainfall distribution is a common constrain to crop production, where dry sowing is commonly practiced before the onset of monsoon, which is difficult to be predicted due climate change and the same influence applies for the distribution of crops (Hooftman et al., 2016) and their establishment. In this 
condition, early sowing causes poor establishment due to the soil moisture deficit for uniform germination and emergence (Bodner et al., 2015). The poor crop stand leads to inefficiency in utilizing available soil moisture due to excess soil moisture evaporation (Bozso et al., 2008) and runoff during rainy period (Bodner et al., 2015). Ultimately germination failure causes seed and household food insecurity (Mucioki et al., 2018). The same water deficit condition restricts the decision-making process of a farmer on reseeding by difficulties in practicality of accessing the field (e.g. a deficit of soil moisture does not allow a prompt re-seeding), economic reasons (the difference between the profit and cost with and without re-seeding), availability of working time (for a prompt intervention) and resource availability (e.g. seed availability, seeder) (Lamichhane et al., 2018). Hence, knowledge on dry sown crops' germination is essential to reduce germination failure under moisture deficit condition. Even though many investigations were made on the germination of various plant species in relation to environmental factors worldwide, only few literatures are available on the germination of field crops under controlled environment condition.

Addressing this knowledge gap in the germination of field crops under dry sowing, the investigation was carried out in three different locations representing three agro climatic zones of Tamil Nadu, India, which produce variety of crops from the $5.36 \mathrm{M}$ ha of rain-fed area from total cultivable area of 8.16 M ha (TN Govt., 2015). Crop failure is a common problem in the region due to poor germination and crop stand (TN Govt., 2015) due to prolonged dry spell. The total estimated value of food crop production losses alone was Rs. 2770 crore $(79.7 \%)$ from 8.68 lakh hectare. Hence, it is essential to overcome the crop failure by developing effective technologies. As part of this objective, this extensive study was made on the germination rate of different dry crops to access the possibility of maximum germination between the dry land crops to ensure the optimum crop stand by better germination immediately after sowing. The test crops were selected from the major pulses, oil seeds and fiber crops cultivated in the study zones (Fig. 1) (Western Zone, North Western Zone and North Eastern Zone) of Northern Tamil Nadu. Groundnut and blackgram accounted for $75 \%$ of total area and the rest of the area (25\%) was occupied by cotton, redgram, cowpea, greengram and sesame cultivation (Fig. 2). These crops were used as test crops and the germination was analyzed with the following objectives: i) To find out the crops having higher germination sown under dry condition ii) To understand the relationship between the germination and environmental factors in rain-fed ecosystem and iii) To study the interactions between the crop germination and different environments.

\section{Materials and methods}

\section{Location}

A field experiment was conducted across three different agro climatic zones of Tamil Nadu namely Western Zone, North Western Zone and North Eastern Zone to study the germination pattern of major dry crops under rain-fed ecosystems during the period of 201617 and 2017-18. In the western zone of Tamil Nadu, the experimental field of Eastern farm, Tamil Nadu Agricultural University is geographically situated at $11^{\circ} 0$ ' North latitude and $76^{\circ} 9^{\prime}$ East longitude at an altitude of $426.7 \mathrm{~m}$ above MSL (Fig. 1). In the North Western Agro-climatic Zone of Tamil Nadu, the experimental field of Regional Research Station, Paiyur is geographically located at $12^{\circ} 21^{\prime}$ ' North latitude and $78^{\circ} 18^{\prime}$ East longitude at an altitude of $490 \mathrm{~m}$ above MSL (Fig. 1). In the North Eastern Agro-climatic Zone, the 


$$
-1205-
$$

experimental field of Agricultural Research Station, Virinjipuram is situated at $12^{\circ} .5^{\prime}$ North latitude and $79^{\circ} .0^{\prime}$ East longitude at an altitude of $231 \mathrm{~m}$ above MSL (Fig. 1).

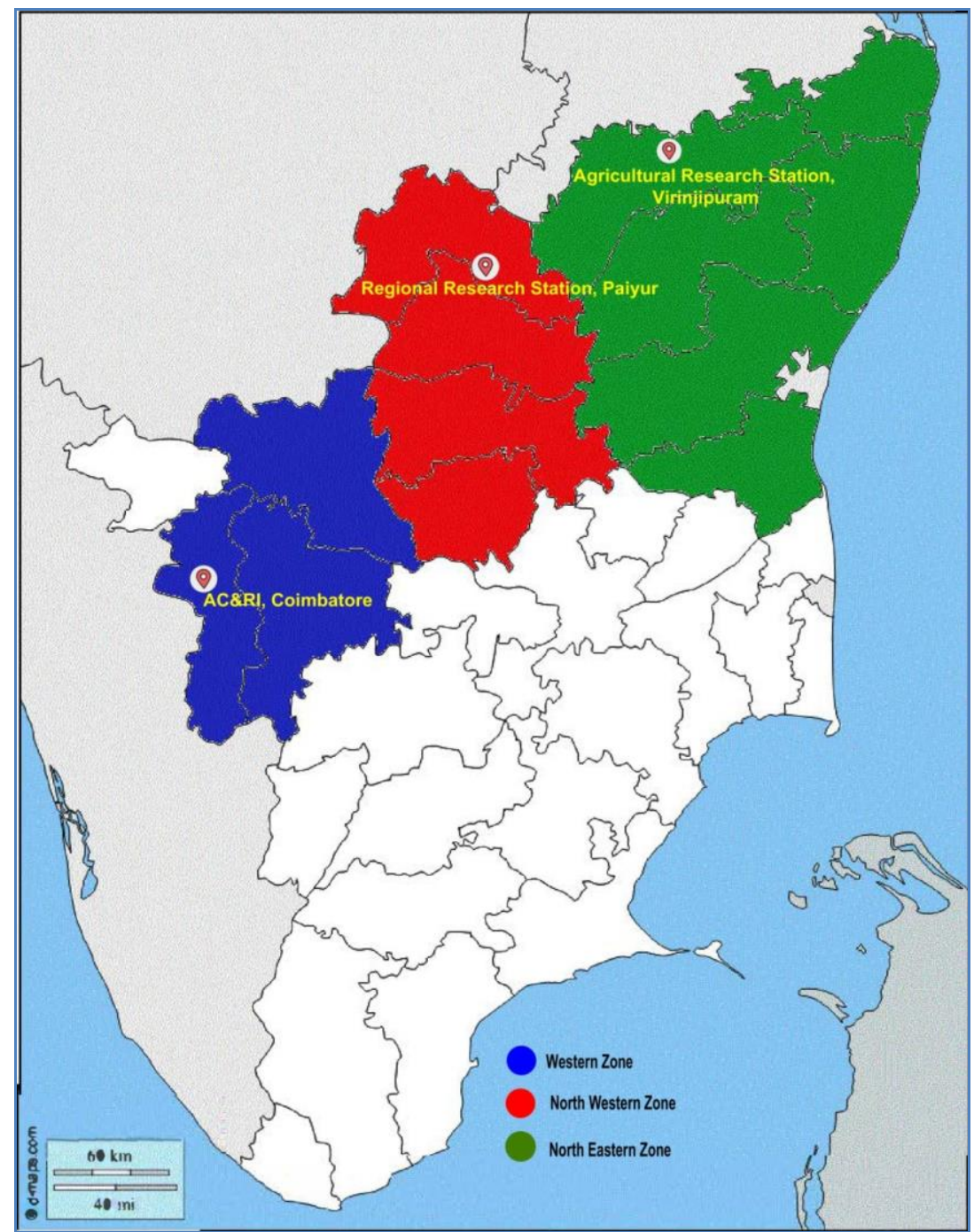

Figure 1. Experimental locations zone wise in northern part of Tamil Nadu, India

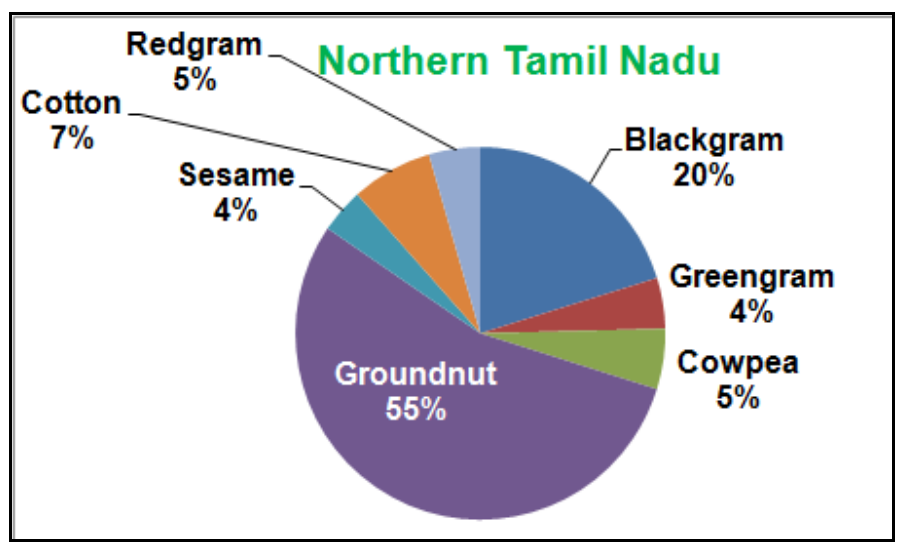

Figure 2. Proportion of test crops cultivation area under rain-fed condition in the study zones of Northern Tamil Nadu, India 


$$
-1206-
$$

\section{Climate and soil}

In all the three locations, five soil samples at $15 \mathrm{~cm}$ depth were collected at random in the experimental field before laying out the experiment during both year and the composite soil sample was obtained by quartering method and processed for analyzing physico-chemical characteristics of the soil. The soil characteristics are presented in Table la. The long-term average annual rainfall is $720.8 \mathrm{~mm}, 918 \mathrm{~mm}$ and $860 \mathrm{~mm}$ at Coimbatore, Paiyur and Virinjipuram, respectively. The weather condition of the different locations was observed and mean values of the first 10 days of sowing were summarized in the Table $1 b$ and the rainfall details were given in Figure 3.

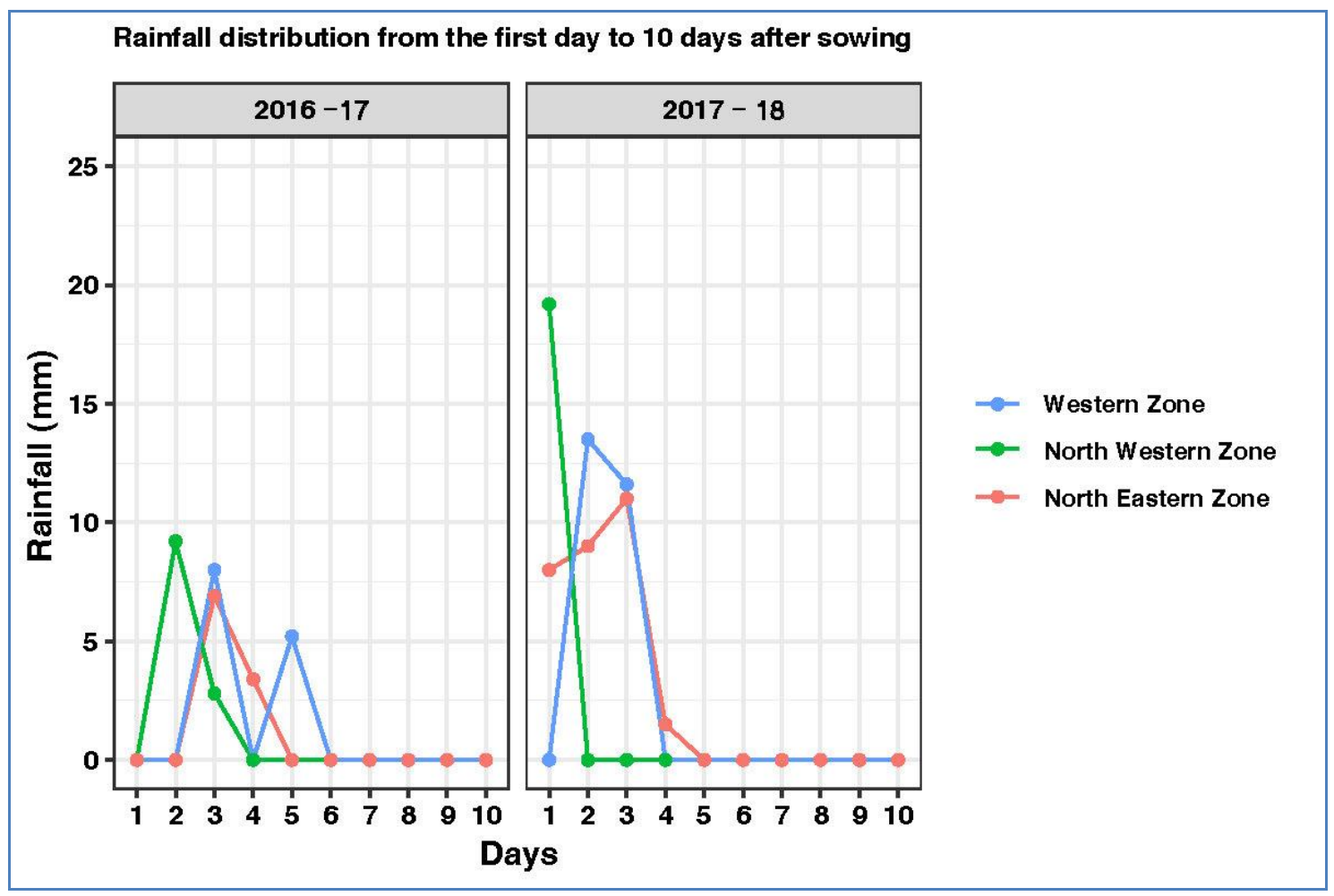

Figure 3. Rainfall distribution from sowing to 10 days after sowing at experimental locations

Table 1a. Soil condition of experiment locations

\begin{tabular}{c|c|c|c|c|c|c}
\hline \multirow{2}{*}{ Soil characteristics } & \multicolumn{3}{|c|}{$\mathbf{2 0 1 6 - 1 7}$} & \multicolumn{3}{c}{ 2017-18 } \\
\cline { 2 - 7 } & WZ & NWZ & NEZ & WZ & NWZ & NEZ \\
\hline Soil nitrogen (kg/ha) & 331 & 198 & 279 & 336 & 198 & 285 \\
Soil phosphorus (kg/ha) & 17.4 & 16.5 & 15.7 & 17.5 & 16.8 & 15.2 \\
Soil potassium (kg/ha) & 611 & 249 & 273 & 613 & 256 & 276 \\
Soil organic matter (\%) & 0.38 & 0.32 & 0.41 & 0.38 & 0.32 & 0.41 \\
Clay (\%) & 35.63 & 9.36 & 23.78 & 35.63 & 9.36 & 23.78 \\
Silt (\%) & 9.95 & 24.25 & 13.65 & 9.95 & 24.25 & 13.65 \\
Sand (\%) & 54.42 & 66.39 & 62.57 & 54.42 & 66.39 & 62.57 \\
Soil pH & 8.3 & 6.1 & 7.8 & 8.3 & 6.1 & 7.8 \\
Soil EC (ds/m) & 1.75 & 0.26 & 0.22 & 1.75 & 0.26 & 0.22 \\
\hline
\end{tabular}


Table $1 \boldsymbol{b}$. Weather condition of experiment locations from the first receipt of rainfall to 10 days after sowing

\begin{tabular}{c|c|c|c|c|c|c}
\hline \multirow{2}{*}{ Weather parameters } & \multicolumn{3}{|c|}{ 2016-17 } & \multicolumn{3}{c}{$\mathbf{2 0 1 7 - 1 8}$} \\
\cline { 2 - 7 } & WZ & NWZ & NEZ & WZ & NWZ & NEZ \\
\hline Rainfall $(\mathrm{mm})$ & 13.2 & 12.0 & 10.3 & 25.1 & 19.2 & 29.5 \\
Soil Moisture \% & 23.5 & 18.5 & 22.8 & 30.4 & 26.4 & 44.7 \\
Maximum Temperature $\left({ }^{\circ} \mathrm{C}\right)$ & 31.7 & 32.71 & 33.12 & 31.31 & 31.06 & 32.01 \\
Minimum Temperature $\left({ }^{\circ} \mathrm{C}\right)$ & 23.4 & 24.56 & 23.92 & 23.67 & 23.19 & 23.34 \\
Relative humidity $(\%)$ & 84.3 & 79.63 & 82.61 & 71.11 & 74.97 & 84.29 \\
Wind speed $(\mathrm{km} / \mathrm{hr})$ & 14.3 & 12.65 & 7.56 & 12.41 & 8.51 & 2.39 \\
Solar radiation $\left(\mathrm{cal} / \mathrm{cm}^{2} /\right.$ day $)$ & 341.76 & 362.18 & 395.7 & 319.03 & 284.82 & 438.91 \\
\hline
\end{tabular}

\section{Crop and variety}

The crops and varieties used for the experiment were blackgram (Vigna mungo) - Co (Coimbatore) 6, greengram (Vigna radiata) - Co (Coimbatore) 8, cowpea (Vigna unguiculata) -VBN (Vamban) 1, groundnut (Arachis hypogaea) - TMV (Tindivanam) 13), sesame (Arachis hypogaea) - TMV (Tindivanam) 7, cotton (Gossypium hirsutum) Co (Coimbatore) 14 and redgram (Cajanus cajan) - CO (Rg) [Coimbatore (Redgram)] 7.

\section{Methodology}

An experiment was conducted with Randomized block design and replicated thrice. The seven different test crops $\left(\mathrm{C}_{1}\right.$ : Blackgram, $\mathrm{C}_{2}$ : Greengram, $\mathrm{C}_{3}$ : Cowpea, $\mathrm{C}_{4}$ : Groundnut, $\mathrm{C}_{5}$ : Sesame, $\mathrm{C}_{6}$ : Cotton, $\mathrm{C}_{7}$ : Redgram) were randomly allotted in each replication.

The layout consisted of 21 experimental plots in three replications having 7 plots in each replication and different test crops were allocated randomly in each replication. Ridges and furrow were formed with the spacing of $45 \mathrm{~cm}$ for redgram and cotton, and $30 \mathrm{~cm}$ for blackgram, greengram, cowpea, groundnut and sesame. The gross plot size was $4.7 \mathrm{~m} \times 2.3 \mathrm{~m}\left(10.81 \mathrm{~m}^{2}\right)$ and net plot size was $3.9 \mathrm{~m} \times 1.5 \mathrm{~m}\left(5.85 \mathrm{~m}^{2}\right)$. Recommended quantity of seeds weighed and counted in Nos. and sown by dibbling method with recommended spacing. The spacing was adopted as $30 \times 10 \mathrm{~cm}$ for blackgram, greengram, groundnut and sesame; $30 \times 15 \mathrm{~cm}$ for cowpea; $45 \times 15$ for cotton and $45 \times 30$ for redgram. Likewise, sowing depth were $2 \mathrm{~cm}, 2 \mathrm{~cm}, 2.5 \mathrm{~cm}, 3 \mathrm{~cm}$, $0.5 \mathrm{~cm}, 2 \mathrm{~cm}$ and $2 \mathrm{~cm}$ for blackgram, cowpea, groundnut, sesame, cotton and redgram respectively. The sowing was carried out before the onset of monsoon at each location. The recommended dose of fertilizer was applied to each treatment individually as per recommendation given in the crop production guide 2014 of TNAU. Germination of various crops individually accounted from the first receipt of rainfall after sowing to 10 DAS and germination percentage of crops were calculated for all three locations. The rainfall distribution from the date of sowing to 10 DAS are presented in Figure 3.

Soil moisture content was estimated from the date of sowing to 10 days after sowing by gravimetric method. For that samples were collected and oven dried at $105^{\circ} \mathrm{C}$ for attaining a constant weight to account dry weight and Equation 1 was used to calculate the soil moisture content and computed as average for the first 10 days of sowing and presented in Table $1 b$. 


$$
\text { Soil moisture }(\%)=\frac{\text { Fresh weight }(\mathrm{g})-\text { dry weight }(\mathrm{g})}{\text { Dry weight }(\mathrm{g})}
$$

\section{Statistical analysis}

The seed germination and soil moisture computed data was subjected to statistical scrutiny as per the procedure given by Gomez and Gomez (1984). The germination, soil and weather data collected from experiment locations were pooled and used for Pearson's correlation test and correlation coefficient value between 0.5 to 1 considered as strong correlation. The graphical representation done by language $\mathrm{R}$, version 4.0.1 was used with package of corrplot (Taiyun and Viliam, 2017). To assess the germination stability over three different locations, AMMI biplot analysis was carried out with agricolae package version 1.4.0 (Menduburu and Yaseen, 2020) in $\mathrm{R}$ version 4.0.1.

\section{Results}

\section{Germination percentage of dry sown crops at different agro climatic zones}

In Western Zone, during 2016-17, the highest Germination Percentage (GP) was recorded in sesame (96.2\%), followed by cotton and cowpea were accounted higher GP of 87.7 and 74 respectively. GP of cowpea was comparable with redgram $(73.4 \%)$, blackgram $(70.3 \%)$ and greengram $(69.8 \%)$. The lowest GP was recorded in groundnut as 58.2 (Table 2). Similarly, during 2017-18, the same trend was observed; the sesame $\left(\mathrm{S}_{5}\right)$ recorded the highest GP of 96.5 . Next to this, cotton $\left(\mathrm{S}_{6}\right)$ and cowpea $\left(\mathrm{S}_{3}\right)$ gave higher GP of 87.2 and 83.2 respectively and these were on par with each other. Greengram $\left(\mathrm{S}_{2}\right)$ was recorded $76.1 \%$ of germination and comparable with blackgram $(75.1 \%)$. The lowest GP was observed in groundnut $\left(\mathrm{S}_{4}\right)$ as 66.8 .

In North Western Zone, the highest germination (90\%) was recorded in sesame, followed by greengram $(86 \%)$, cotton $(81.7 \%)$, blackgram $(81.4 \%)$ and redgram (80.7\%) during 2016-17. The cowpea and groundnut alone recorded lesser than $80 \%$ germination as $74.0 \%$ and the lowest of $71.9 \%$, respectively (Table 2). For the duration of 2017-18, the highest germination was observed in greengram $(95.3 \%)$ and it was comparable with cowpea $\left(S_{3}\right)$, blackgram $\left(S_{1}\right)$ and groundnut $\left(S_{4}\right)$. The germination of cotton was comparable with groundnut. The lowest germination was recorded in sesame $\left(\mathrm{S}_{5}\right)$ as $68.3 \%$ (Table 2).

In 2016-17, the highest GP was recorded in sesame as $90.6 \%$. Followed by cotton, redgram, cowpea, greengram, groundnut and blackgram in the case of which the recorded GP was of 82.3, 79.9, 79.5, 78.5, 78.1 and 76.4, respectively and these were comparable with each other (Table 2). During 2017-18, in the case of cowpea $\left(\mathrm{S}_{3}\right)$ a higher GP of 91.1 was recorded and this was comparable with the germination of groundnut $\left(\mathrm{S}_{4}\right)$, cotton $\left(\mathrm{S}_{6}\right)$, blackgram $\left(\mathrm{S}_{1}\right)$ and greengram $\left(\mathrm{S}_{2}\right)$. The lowest germination was observed in sesame $\left(\mathrm{S}_{5}\right)$ as $73.1 \%$ (Table 2).

\section{Influence of weather and soil moisture on germination percentage of dry sown crops}

The correlation test results between germination percentage and weather factors were presented in Table 3. The GP of blackgram, greengram, cowpea, groundnut, cotton and redgram exhibited strong positive correlation with soil moisture. Meanwhile, sesame exhibited negative non-significant correlation with soil moisture at germination stage. 
Likewise, non-significant positive correlation was observed between rainfall and blackgram, greengram, cowpea, groundnut, cotton and redgram; and negative nonsignificant correlation was observed with sesame. The relationship between GP and temperature, relative humidity and solar radiation was non-significant. Wind speed exhibited strong positive correlation with germination of sesame and it was negative nonsignificant with blackgram, greengram, cowpea, groundnut, cotton and redgram (Table 3).

Table 2. Germination percentage of rainfed dry sown crops at various agro climatic zones of Tamil Nadu

\begin{tabular}{c|c|c|c|c|c|c}
\hline \multirow{2}{*}{ Crop } & \multicolumn{3}{|c|}{$\mathbf{2 0 1 6 - 1 7}$} & \multicolumn{3}{|c|}{$\mathbf{2 0 1 7 - 1 8}$} \\
\cline { 2 - 7 } & WZ & NWZ & NEZ & WZ & NWZ & NEZ \\
\hline BG & $70.3 \pm 0.835^{\text {de }}$ & $81.4 \pm 0.669^{\text {cd }}$ & $76.4 \pm 1.185^{\mathrm{e}}$ & $75.1 \pm 1.513^{\mathrm{e}}$ & $94.3 \pm 0.781^{\mathrm{a}}$ & $90.3 \pm 0.754^{\mathrm{ab}}$ \\
GG & $69.8 \pm 0.722^{\mathrm{e}}$ & $86.1 \pm 0.941^{\mathrm{b}}$ & $78.5 \pm 1.216^{\mathrm{cd}}$ & $76.1 \pm 1.411^{\mathrm{e}}$ & $95.2 \pm 1.244^{\mathrm{a}}$ & $89.6 \pm 0.577^{\mathrm{ab}}$ \\
CP & $74.0 \pm 1.763^{\mathrm{c}}$ & $79.7 \pm 0.679^{\mathrm{d}}$ & $79.5 \pm 0.487^{\mathrm{cd}}$ & $83.2 \pm 2.316^{\mathrm{c}}$ & $95.2 \pm 0.700^{\mathrm{a}}$ & $91.2 \pm 1.676^{\mathrm{a}}$ \\
GN & $58.2 \pm 2.061^{\mathrm{f}}$ & $71.9 \pm 0.623^{\mathrm{e}}$ & $78.1 \pm 0.742^{\mathrm{d}}$ & $66.8 \pm 1.189^{\mathrm{f}}$ & $94.0 \pm 1.393^{\mathrm{a}}$ & $90.9 \pm 1.803^{\mathrm{a}}$ \\
SM & $96.2 \pm 0.024^{\mathrm{a}}$ & $90.0 \pm 0.699^{\mathrm{a}}$ & $90.6 \pm 1.011^{\mathrm{a}}$ & $96.6 \pm 0.769^{\mathrm{a}}$ & $68.3 \pm 1.519^{\mathrm{c}}$ & $73.1 \pm 1.732^{\mathrm{c}}$ \\
CT & $87.7 \pm 1.626^{\mathrm{b}}$ & $81.7 \pm 0.420^{\mathrm{c}}$ & $82.3 \pm 1.201^{\mathrm{b}}$ & $87.2 \pm 1.452^{\mathrm{b}}$ & $89.7 \pm 1.885^{\mathrm{b}}$ & $90.3 \pm 2.030^{\mathrm{a}}$ \\
RG & $73.4 \pm 1.258^{\mathrm{cd}}$ & $80.7 \pm 1.036^{\mathrm{cd}}$ & $79.9 \pm 0.801^{\mathrm{c}}$ & $79.8 \pm 1.302^{\mathrm{d}}$ & $88.4 \pm 1.192^{\mathrm{b}}$ & $86.6 \pm 1.272^{\mathrm{b}}$ \\
SEd & 2.2 & 2.6 & 2.8 & 2.7 & 2.1 & 2.4 \\
CD (P=0.05) & 4.3 & 5.2 & 5.7 & 5.6 & 4.4 & 4.8 \\
\hline
\end{tabular}

Values presented in table are the mean of three replicates. Values fallowed by \pm values are standard deviation of the germination and same lower-case letters are not significantly different among different crop germination percentage. BG - Blackgram; GG - Greengram; CP - Cowpea; GN - Groundnut; SM - Sesame; CT - Cotton; RG - Redgram

Table 3. Correlation between the germination of dry sown crops with soil moisture and weather factors

\begin{tabular}{c|c|c|c|c|c|c}
\hline Crop & Soil moisture (\%) & Rainfall (mm) & Temp. $\left({ }^{\circ} \mathbf{C}\right)$ & RH $(\%)$ & $\begin{array}{c}\text { Wind speed } \\
(\mathbf{k m} / \mathbf{h r})\end{array}$ & $\begin{array}{c}\text { Solar radiation } \\
(\mathbf{c a l} / \mathbf{c m} / \mathbf{d a y})\end{array}$ \\
\hline BG & $0.63^{* *}$ & $0.19^{\mathrm{NS}}$ & $-0.30^{\mathrm{NS}}$ & $-0.13^{\mathrm{NS}}$ & $-0.67^{\mathrm{NS}}$ & $0.005^{\mathrm{NS}}$ \\
GG & $0.55^{* *}$ & $0.15^{\mathrm{NS}}$ & $-0.14^{\mathrm{NS}}$ & $-0.16^{\mathrm{NS}}$ & $-0.59^{\mathrm{NS}}$ & $-0.014^{\mathrm{NS}}$ \\
CP & $0.64^{*}$ & $0.27^{\mathrm{NS}}$ & $-0.49^{\mathrm{NS}}$ & $-0.32^{\mathrm{NS}}$ & $-0.64^{\mathrm{NS}}$ & $-0.103^{\mathrm{NS}}$ \\
GN & $0.55^{*}$ & $0.11^{\mathrm{NS}}$ & $-0.20^{\mathrm{NS}}$ & $-0.03^{\mathrm{NS}}$ & $-0.82^{\mathrm{NS}}$ & $0.156^{\mathrm{NS}}$ \\
SM & $-0.48^{\mathrm{NS}}$ & $-0.10^{\mathrm{NS}}$ & $0.39^{\mathrm{NS}}$ & $-0.02^{\mathrm{NS}}$ & $0.72^{* *}$ & $-0.041^{\mathrm{NS}}$ \\
CT & $0.57^{* *}$ & $0.29^{\mathrm{NS}}$ & $-0.78^{\mathrm{NS}}$ & $-0.08^{\mathrm{NS}}$ & $-0.31^{\mathrm{NS}}$ & $-0.123^{\mathrm{NS}}$ \\
RG & $0.66^{* *}$ & $0.28^{\mathrm{NS}}$ & $-0.31^{\mathrm{NS}}$ & $-0.28^{\mathrm{NS}}$ & $-0.69^{\mathrm{NS}}$ & $0.005^{\mathrm{NS}}$ \\
\hline
\end{tabular}

Correlation co-efficient $1 \%=0.57,5 \%=0.43$

*Significant at $5 \%$ level. **Significant at $1 \%$ level. NS: Non significant

\section{Influence of soil factors on germination percentage of dry sown crops}

The results of correlation between soil factors and germination percentage were presented in Table 4. Germination of sesame exhibited positive correlation with soil nutrients (Nitrogen, Phosphorus and Potassium), clay content, soil $\mathrm{pH}$ and Ec at initial stage of germination. Likewise, cotton also positively correlated with soil nutrients (Nitrogen, Phosphorus and Potassium), soil organic matter, clay content, soil $\mathrm{pH}$ and Ec. In other side, sesame and cotton exhibited non-significant negative correlation with silt and sand content of soil. Germination of blackgram, greengram, cowpea, groundnut and 
redgram expressed non-significant negative correlation with soil nutrients (Nitrogen, Phosphorus and Potassium), soil organic matter, clay content, soil $\mathrm{pH}$ and Ec. Meanwhile, these crops expressed significant positive correlation with silt and sand content of soil.

Table 4. Correlation between the germination of dry sown crops with soil factors

\begin{tabular}{|c|c|c|c|c|c|c|c|c|c|}
\hline Crop & Soil N & Soil $\mathrm{P}_{2} \mathrm{O}_{5}$ & Soil $\mathrm{K}_{2} \mathrm{O}$ & Soil OM & Clay & Silt & Sand & Soil pH & Soil EC $(\mathrm{dS} / \mathrm{m})$ \\
\hline BG & $-0.67^{\mathrm{NS}}$ & $-0.46^{\mathrm{NS}}$ & $-0.71^{\mathrm{NS}}$ & $0.34^{\mathrm{NS}}$ & $-0.71^{\mathrm{NS}}$ & $0.65^{* *}$ & $0.74^{* *}$ & $-0.64^{\mathrm{NS}}$ & $-0.69^{\mathrm{NS}}$ \\
\hline GG & $-0.79^{\mathrm{NS}}$ & $-0.46^{\mathrm{NS}}$ & $-0.79^{\mathrm{NS}}$ & $-0.45^{\mathrm{NS}}$ & $-0.82^{\mathrm{NS}}$ & $0.77^{* *}$ & $0.84^{* *}$ & $-0.75^{\mathrm{NS}}$ & $-0.76^{\mathrm{NS}}$ \\
\hline $\mathrm{CP}$ & $-0.43^{\mathrm{NS}}$ & $-0.32^{\mathrm{NS}}$ & $-0.48^{\mathrm{NS}}$ & $-0.21^{\mathrm{NS}}$ & $-0.47^{\mathrm{NS}}$ & $0.42^{\mathrm{NS}}$ & $0.50^{*}$ & $-0.41^{\mathrm{NS}}$ & $-0.48^{\mathrm{NS}}$ \\
\hline GN & $-0.57^{\mathrm{NS}}$ & $-0.63^{\mathrm{NS}}$ & $-0.77^{\mathrm{NS}}$ & $-0.10^{\mathrm{NS}}$ & $-0.62^{\mathrm{NS}}$ & $0.51^{*}$ & $0.72^{* *}$ & $-0.49^{\mathrm{NS}}$ & $-0.78^{\mathrm{NS}}$ \\
\hline $\mathrm{SM}$ & $0.58^{* *}$ & $0.49^{*}$ & $0.67^{* *}$ & $0.22^{\mathrm{NS}}$ & $0.61^{* *}$ & $-0.54^{\mathrm{NS}}$ & $-0.67^{\mathrm{NS}}$ & $0.53^{*}$ & $0.66^{* *}$ \\
\hline $\mathrm{CT}$ & $0.19^{\mathrm{NS}}$ & $0.05^{\mathrm{NS}}$ & $0.18^{\mathrm{NS}}$ & $0.09^{\mathrm{NS}}$ & $0.18^{\mathrm{NS}}$ & $-0.16^{\mathrm{NS}}$ & $-0.18^{\mathrm{NS}}$ & $0.16^{\mathrm{NS}}$ & $0.16^{\mathrm{NS}}$ \\
\hline RG & $-0.53^{\mathrm{NS}}$ & $-0.44^{\mathrm{NS}}$ & $-0.62^{\mathrm{NS}}$ & $-0.21^{\mathrm{NS}}$ & $-0.58^{\mathrm{NS}}$ & $0.51^{*}$ & $0.62^{* *}$ & $-0.49^{\mathrm{NS}}$ & $-0.62^{\mathrm{NS}}$ \\
\hline
\end{tabular}

Correlation co-efficient $1 \%=0.57,5 \%=0.43$

*Significant at 5\% level. **Significant at $1 \%$ level. NS: Non significant

\section{Stability of germination percentage across the different environments}

From the AMMMI stability analysis, redgram $\left(\mathrm{C}_{1}\right)$ was considered to be stable over different environments and it was followed by cowpea $\left(C_{3}\right)$, greengram $\left(C_{2}\right)$ and blackgram $\left(\mathrm{C}_{1}\right)$. Though these crops are stable over environments, they are considered as least contributors for the crop $\times$ environment interactions. Cotton $\left(\mathrm{C}_{6}\right)$, Sesame $\left(\mathrm{C}_{5}\right)$ and Groundnut $\left(\mathrm{C}_{4}\right)$ were prognosticated to be unstable crops over environment, but they contributed most for the crop germination $\times$ environment interactions.

Among the Environments, E5 (NWZ, 2017-18) had the highest score on PC1 axis and higher mean germination, which is considered as more unstable environment. Whereas E2 (NWZ, 2016-17) and E3 (NEZ, 2016-17) had the lowest scores on PC1 axis and they are prognosticated to be more stable environments.

AMMI biplot PC1 vs PC2 shows the stability of environments and crops as well as crop $\times$ environment interactions. The crop redgram $\left(\mathrm{C}_{7}\right)$ is considered to be the stable crop over the environments. Environments E3 (NEZ, 2016-17) and E4 (WZ, 2017-18) gave stable performance for all the crops. The crop sesame $\left(\mathrm{C}_{5}\right)$ performed better in Environments $\mathrm{E} 1$ (WZ, 2016-17), E2 (NWZ, 2016-17), E3 (NEZ, 2016-17), E4 (WZ, 2017-18). Cotton (C6) has the highest overall mean among the crops and over the environments.

\section{Discussion}

\section{Germination performance of test crops}

Western zones

The increased GP of sesame and cotton (Table 2) was due to the sufficiency in mean available soil moisture (23.5\%) up to 10 DAS from the first receipt of rainfall to imbibe the seeds through hydration and initiation of metabolic activity (Obroucheva, 2017). In this same moisture condition, GP of blackgram, greengram, cowpea, groundnut and redgram was reduced $27 \%, 27.4 \%, 23 \%$ and $23.7 \%$ respectively over the Germination Percentage of sesame (Fig. 4) during 2016-17 and the same trend was followed in 201718 (Table 2). This was due to the sensitivity of legume crops to the soil salt concentration by accumulating higher salt (Keating and Fisher, 1985) from the saline soil, which lead to reduced water uptake osmotically or imbalance in nutrient uptake 
ionically and then affect the metabolic and enzyme activity during the germination process (Bewley et al., 2013). This was in line with the findings of Dash and Panda (2001), who observed reduced germination of greengram, blackgram and cowpea in saline soils. Among the legume crops, cowpea performed relatively better germination; it might be due to the little higher tolerance to salinity by accumulating low salts (Keating and Fisher, 1985) than other legume crops. The lowest germination of groundnut was might be the reason of relatively higher sensitiveness to the soil salinity. This is in line with the findings of Shalhevet et al. (1969), who observed 50\% reduced germination of groundnut in saline soil over control. In this saline condition, higher germination of sesame and cotton was representing the tolerance to salinity against other crops. This agreed with the findings of Eynard et al. (2005), who reported, semi tolerance of sesame and tolerance of cotton to soil salinity. Similarly, Yousif et al. (1972) reported that, sesame shows high tolerance to soil salinity at germination stage than in other growth and development stages. This tolerance may be the reason of osmotic adjustment by accumulation of compatible solutes and regulatory mechanism for ion transport (Ashraf and Harris, 2004).

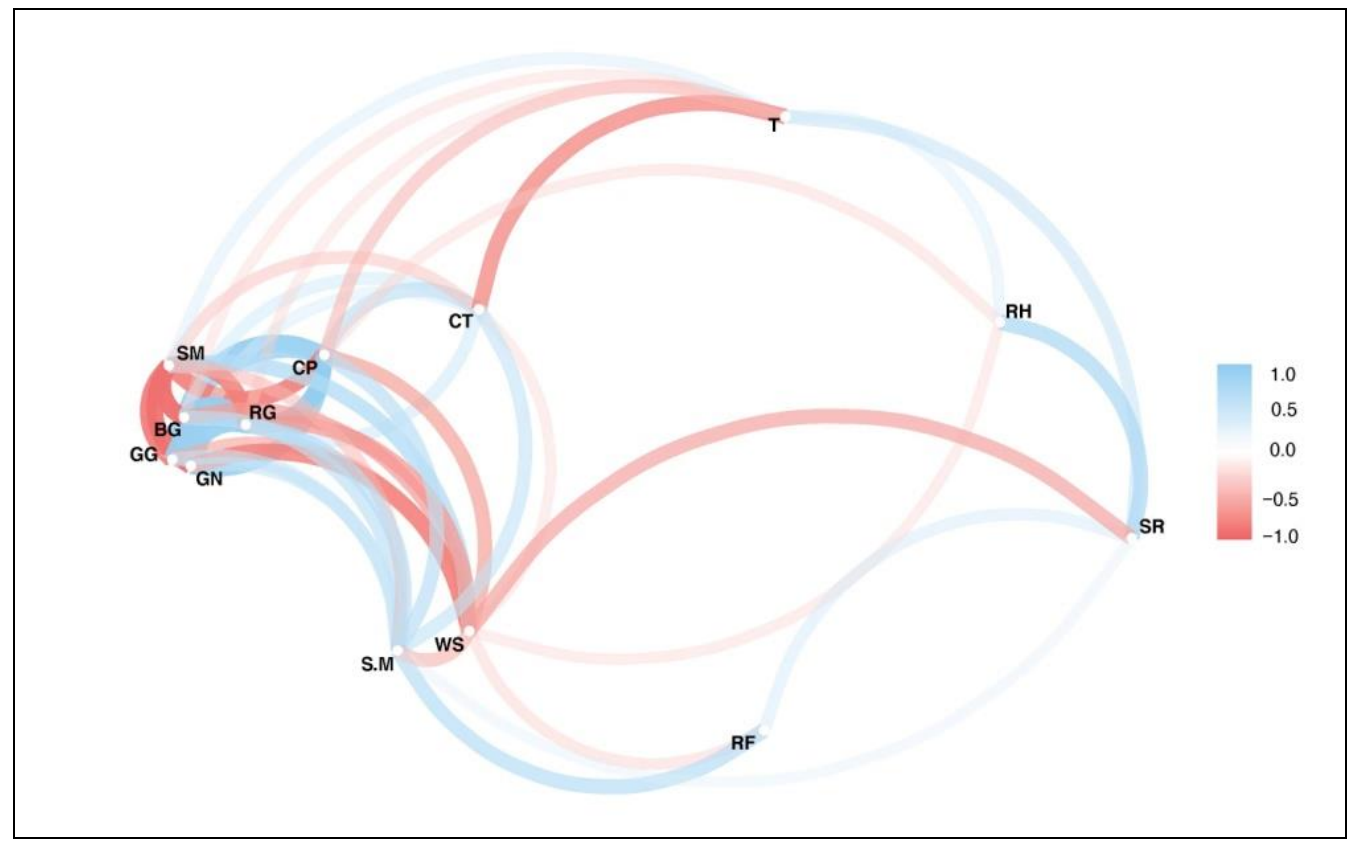

Figure 4. Correlation network between the germination percentage of test crops and climatic factors. BG: Blackgram; GG: Greengram; CP: Cowpea; GN: Groundnut; SM: Sesame; CT: Cotton; RG: Redgram; S.M: Soil Moisture (\%);RF: Rainfall (mm); T: Temperature $\left({ }^{\circ} \mathrm{C}\right)$; RH:Relative humidity (\%); WS: Wind speed $(\mathrm{km} / \mathrm{hr}) ;$ SR: Solar radiation $\left(\mathrm{cal} / \mathrm{cm}^{2} /\right.$ day)

\section{North western zones}

During 2016-17, increased germination of sesame (Table 2) with mean soil moisture of $18.5 \%$ shows its ability to germinate under scarce soil moisture condition due to the quick imbibitions by lower water need of small size seeds (Wu and $\mathrm{Du}, 2007$ ) to initiate the metabolic activities of germination. These results agree with the findings of Kaya (2008), who reported that small seeds show lower water uptake than bold seeds in chickpea. The poor germination of cowpea and groundnut (Table 2) was due to 
insufficient soil moisture to imbibe the seeds, since bold seeds can uptake more water for germination over small seeds (Kaya et al., 2008). In contradiction, Gómez (2004) reported as bold seeds have more germination rate compared to small seeds due to its more reserve. But, it is decided by ecological external factors such as rainfall, soil moisture, temperature etc., (Parker et al., 2006).

Like seed size, depth of sowing also might be contributed to significant difference between the crops GP (Amini et al., 2015). Shallow sowing of sesame seeds $(1.5 \mathrm{~cm})$ might be the reason for increased germination (Florentine et al., 2016) due to effectiveness of soil moisture and other physical properties of soil (Xu et al., 2017). The increased sowing depth of cowpea and groundnut reduced the germination over other crops under dry sowing condition due to restriction for soil moisture availability to imbibe the seeds (Dinelli et al., 2013). This is against the findings of Schillinger et al. (2017), who reported sowing at greater depth is generally practiced to reach adequate soil moisture for germination. But, this concept may vary in different ecological condition (Lamichhane et al., 2018) like rainfed agro ecosystems, where dry seeding is practiced before the onset of monsoon. If, rainfall is not sufficient to moist the sowing depth of any crops will lead to germination failure by partial imbibitions due to soil moisture deficit.

During, 2017-18 the highest germination was observed in greengram and it was comparable with cowpea $\left(\mathrm{S}_{3}\right)$, blackgram $\left(\mathrm{S}_{1}\right)$ and groundnut $\left(\mathrm{S}_{4}\right)$ (Table 2). The increased germination of these crops might be the reason of increased mean soil moisture $(26.4 \%)$ by higher rainfall than in the previous cropping season and boldness of these seeds might gave higher germination potential with sufficient moisture condition over small seeds (Erskine, 1996). In addition to this, native soil of red sandy loam contains less clay facilitating germination better by offering favorable environment (Prasad, 2017) to blackgram, greengram, cowpea and groundnut and the same decreased the germination of cotton. The lowest GP was observed in sesame $\left(\mathrm{S}_{5}\right)$ as 68.3 due to high intense rainfall (19.2 $\mathrm{mm}$ within $8 \mathrm{~h}$ ) immediately after sowing, which dispersed the small sesame seeds by exerting long floating time (Sarneel, 2013) in beds and got run off due to shallow sowing of sesame seeds and soil characteristics (Tekiela and Barney, 2013) as poor clay content of native soil (high sand) may have reduced the stickiness of seeds and favored seed displacement.

\section{North eastern zone}

Similar to NWZ, germination of sesame was increased (Table 2) with soil moisture content of $22.8 \%$ with lower rainfall of $10.3 \mathrm{~mm}$ during 2016-17 and the next year (2017-18) germination decreased (Table 2) due to increased soil moisture of $44.7 \%$ by heavy rainfall $(29.5 \mathrm{~mm})$ over the first 3 days of sowing. This intense excessive rainfall might have dispersed the small sesame seeds (Sarneel, 2013) and water saturation reduced the germination due to reduced oxygen concentration (Tian and Arihara, 2003), which is necessary for respiration. Germination of redgram, greengram, cowpea, blackgram and groundnut was lesser (Table 2) than $80 \%$ due to insufficient moisture $(22.8 \%)$ to imbibe the bold seeds (Dinelli et al., 2013) and higher sowing depth during 2016-17. Interestingly, except groundnut these GPs were lower than the germination observed with $15.5 \%$ soil moisture at NWZ during 2016-17. This was might be the negative effect of native soil $\mathrm{pH}$ (7.8) on seed germination biological systems (Basto et al., 2013). Next year GP increased in cowpea, groundnut, cotton, blackgram, greengram and redgram (Table 2) by more than $80 \%$ due to its greater germination potential under optimum soil moisture condition of $44.7 \%$ (Gomez, 2004). 


\section{Influence of weather and soil moisture on germination}

Except sesame, all the crops showed significant positive correlation with soil moisture (Fig. 4) due to increased seed size, which required high soil moisture for imbibitions of the seed completely (Kaya et al., 2008) to activate the metabolic process of germination. Statistically, soil moisture alone caused significant positive influence on germination of blackgram, greengram, cowpea, groundnut, cotton and redgram (Fig. 4). This was in line with the findings of Bewley et al. (2013) who reported, decreasing soil moisture potential reduces water uptake for imbibitions and germination got reduced. It might be assumed that the failure of live seeds to germinate under insufficient moisture condition (Evans and Therington, 1990), which is not sufficient to species specific hydration level of seeds (Hadas and Stibbe, 1973).

Germination of these crops excluding sesame expressed negative relationship with temperature (Tang and Chen, 2017) and wind speed (Fig. 4) (Jacobson, 1998), which might be the reason of increased temperature and wind speed leads evaporation demand in atmosphere and subsequently reduced soil moisture (Rao, 2008). Similarly, Dove (2010) stated that, a warmer climate may increase evaporation and decrease soil moisture, which would negatively affect germination. Most of the research dealt with the relationship between germination and soil temperature and fewer reports are available on atmospheric temperature. The atmospheric temperature indirectly influences germination of seeds by altering the soil temperature, which can influence germination through initiating enzyme activities and promoting germination under optimum condition or inhibit the germination by above the optimum level (Mohamed et al., 1988) through the synthesis of hormones involved in seed germination (Xu et al., 2017).

Against to these results, correlation between germination of sesame and soil moisture percentage is non-significant and expressed negative correlation in the analysis (Fig. 4). This implies that, deficit soil moisture is not a limiting factor for sesame germination at all three environments, since it gave maximum germination with $18.5 \%$ soil moisture at NWZ. The negative relationship between sesame germination and soil moisture was due to the poor germination under increased soil moisture by oxygen deficit (Tian and Arihara, 2003). This was in line with findings of Fawusi and Agboola (1980), who reported reduced germination of millets with increased soil moisture percentage due to inhibition of seed respiration by limited oxygen. Likely, germination of sesame negatively correlated with rainfall and relative humidity. This was due to the positive relationship between the soil moisture and rainfall and reduced soil moisture loss by evaporation due to higher relative humidity (Salvucci, 2012). Sesame germination positively correlated with temperature and wind speed; negatively correlated with soil moisture, rainfall and relative humidity (Fig. 4), which might have increased wind speed and temperature, decreased the excess soil moisture by evaporation and saved the seed from stagnation and provided sufficient oxygen (Tian and Arihara, 2003). Influence of solar radiation was non-significant with GP of all the test crops.

\section{Influence of soil factors on germination}

From the results, except for sesame and cotton, all crops showed negative correlation with soil nitrogen, phosphorus, potassium, organic matter, clay content, soil $\mathrm{pH}$ and EC (Fig. 5). This was due to the sensitivity of legume crops to soil salinity (Mass and Hoffman, 1977) and high concentration of soil nutrients may have decreased the germination rate by reduced imbibitions (Durrant and Mash, 1989) due to the lower 
water potential at soil portion around the seed (Hegarty, 1976). These findings agree with Luzuriaga et al. (2006), who reported, decreased germination under increased soil salinity, $\mathrm{pH}$ and soil nutrient concentration in various studies. Likewise, positive correlation was observed with soil silt and sand content (Fig. 5). Sand content expressed positive correlation with germination of blackgram, greengram, cowpea, groundnut and redgram (Jepsen et al., 2011). The sand and silt content might have helped to avoid water stagnation by providing better aeration and drainage facility, which helps the exchange of more oxygen (Benvenuti, 2003).

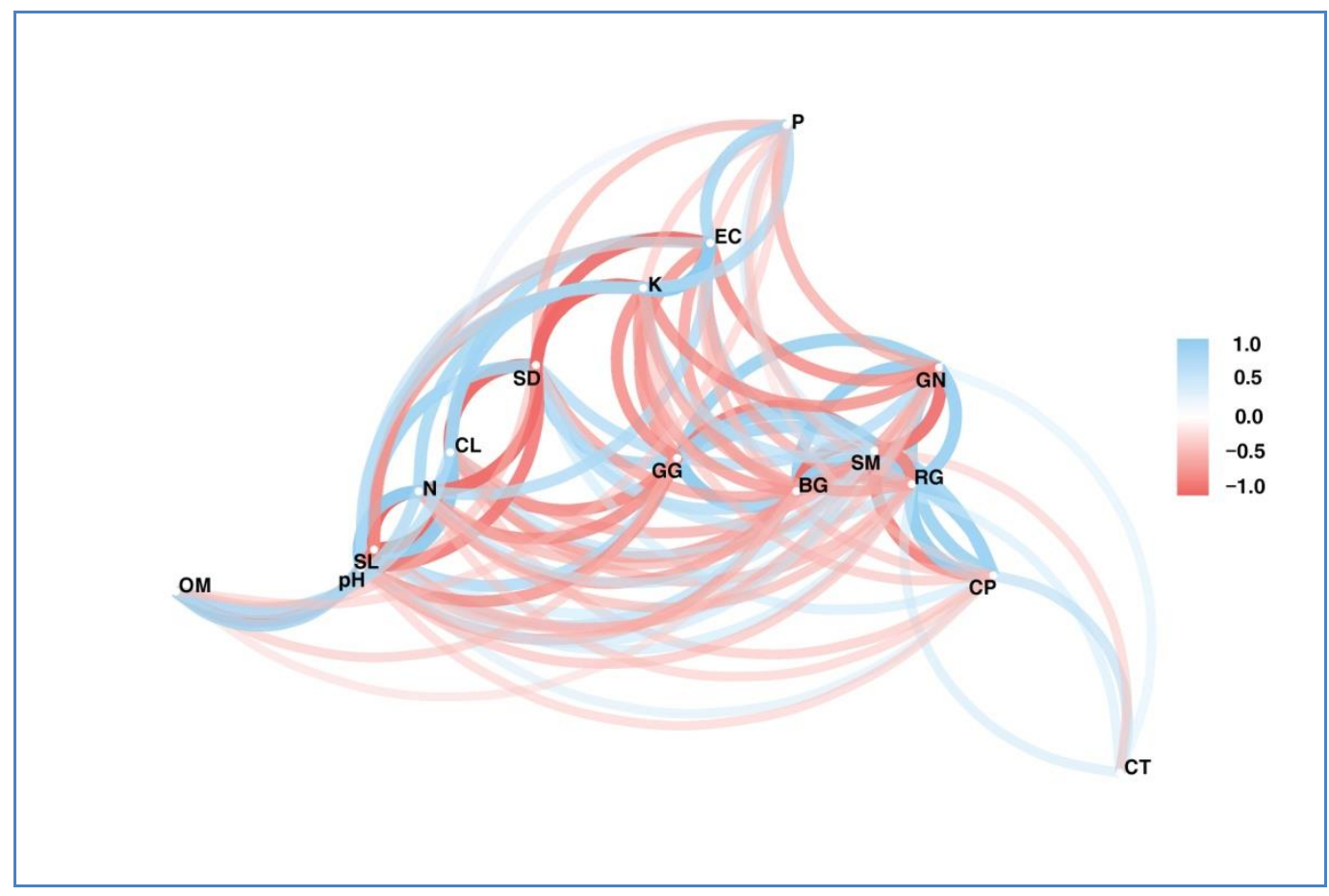

Figure 5. Correlation network between the germination percentage of test crops and soil factors \{BG: Blackgram; GG: Greengram; CP: Cowpea; GN: Groundnut; SM: Sesame; CT: Cotton; RG: Redgram; N: Soil Nitrogen (kg/ha); P: Soil Phosphorus (kg/ha); K: Soil Potassium (kg/ha); OM: Soil organic matter(\%); CL: Clay (\%); SL: Silt (\%); SD: Sand (\%); pH: Soil PH;EC: Soil Ec $(d S / m)$

Sesame and cotton show positive relationship with soil nitrogen, phosphorus and potassium, soil organic matter, clay content, soil pH and EC (Fig. 5) due to the tolerance for high salt concentration (Eynar et al., 2012), on the other hand it shows negative correlation with silt and sand content, which easily allows the sesame seeds to disperse under high rainfall (Sarneel, 2013) and reduces the imbibitions of cotton seeds by quick water loss more than clay soil (Michael, 2008).

\section{Stability of germination percentage across the different environments}

Redgram $\left(\mathrm{C}_{7}\right)$ was considered to be stable over different environments and it was followed by cowpea $\left(\mathrm{C}_{3}\right)$, greengram $\left(\mathrm{C}_{2}\right)$ and blackgram $\left(\mathrm{C}_{1}\right)$. Though these crops are stable over environments, they are considered as least contributors for the Crop $\times$ Environment interactions (Figs. 6 and 8). Stability of redgram over different environment was due to the suitability with wide range of soil types without water stagnation and 
moderate saline tolerance (Saxena, 2010). Likewise, redgram is a suitable crop for moisture stress environment due to large food reserve to survive under drought condition and also have in-built compensation mechanism for survival (Saxena, 2008).

Cotton $\left(\mathrm{C}_{6}\right)$, Sesame $\left(\mathrm{C}_{5}\right)$ and Groundnut $\left(\mathrm{C}_{4}\right)$ were prognosticated to be unstable crops over environment, but they contributed most for the Crop $\times$ Environment interactions (Figs. 6 and 8). This was due to the significant influence of environmental factors, such as soil texture and rainfall. Apart from the soil salinity, the fine soil texture (higher clay content) of WZ and NEZ recorded higher cotton germination over NWZ and increased rainfall significantly increased the germination of cotton (Sehgal, 1991). The increased rainfall immediately after sowing might be the reason for reduced germination of sesame due to lack of oxygen (Tian and Arihara, 2003) and seed dispersal (Sarneel, 2013) at the same time germination was increased under soil moisture deficit condition (ZechMatterne et al., 2015). Similarly, Van Rheenen (1979) stated that, sesame grow on relatively dry, light and well drained soils and excessive rainfall may limit the sesame production. The higher interaction of groundnut germination with the environment was due to the positive impact of rainfall, soil moisture (Ramakrishna et al., 2006) and negative impact of increased soil clay content (Ayalew, 2015) and salt concentration (Shalhevet et al., 1969). Cotton $\left(\mathrm{C}_{6}\right)$, sesame $\left(\mathrm{C}_{5}\right)$ and cowpea $\left(\mathrm{C}_{3}\right)$ performed above the overall mean and are considered to adapt at all the environments and therefore, generalists based on the standard performance at all the locations.

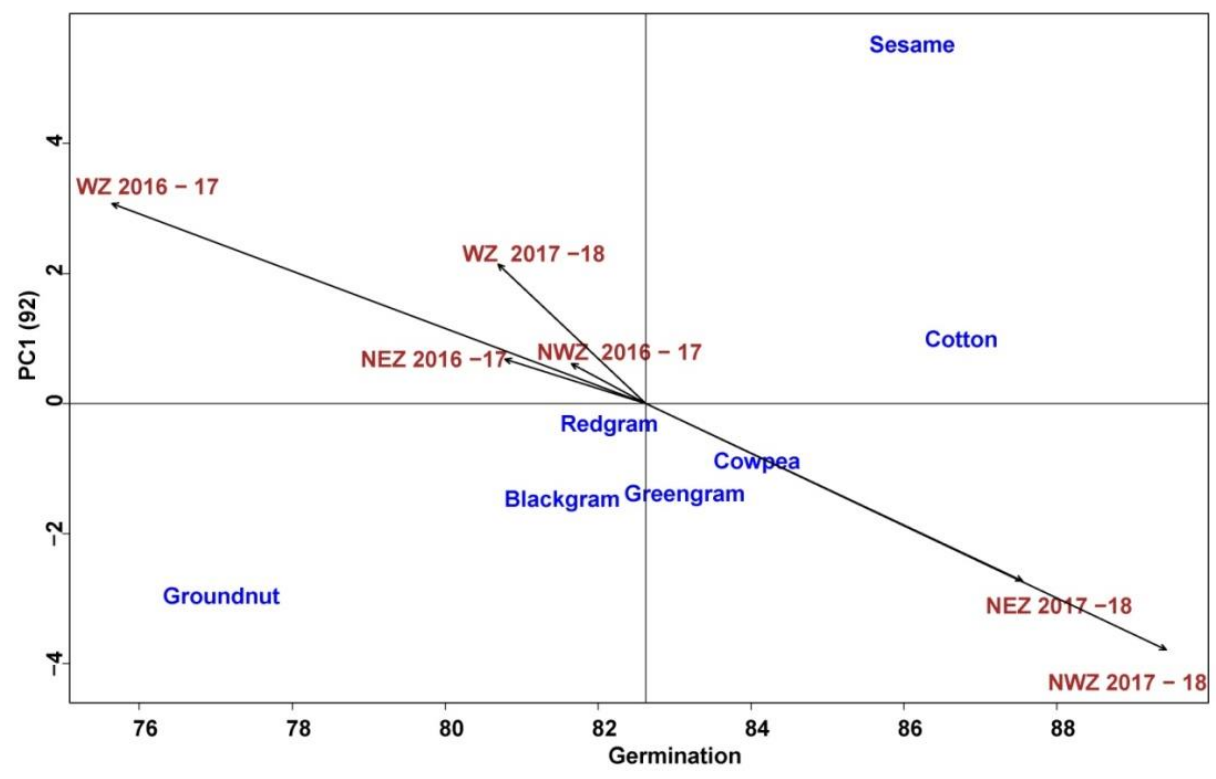

Figure 6. AMMI biplot showing the main and interaction (PC1) effects of both crops and environments on germination percentage. An estimate of the Crop Environment interaction effect for a specific Crop-environment combination is the product of their corresponding interaction PC1 scores

Among the Environments, E5 (NWZ, 2017-18) had the highest score on PC1 axis and higher mean germination which is considered as a more unstable environment (Figs. 7 and 8). Because, intense rainfall of $19.2 \mathrm{~mm}$ within $8 \mathrm{~h}$ is not possible at all time. Whereas E2 (NWZ, 2016-17) and E3 (NEZ, 2016-17) had the lowest scores on PC1 axis and they are prognosticated to be more stable environments. AMMI biplot PC1 vs PC2 
(Fig. 7) shows the stability of environments and crops as well as crop germination $\mathrm{X}$ Environment interactions. The crop redgram $\left(\mathrm{C}_{7}\right)$ is considered to be the stable crop over the environments. Environments E3 (NEZ, 2016-17) and E4 (WZ, 2017-18) gave stable performance for all the crops. The crop sesame $\left(\mathrm{C}_{5}\right)$ performed better in Environments E1 (WZ, 2016-17), E2 (NWZ, 2016-17), E3 (NEZ, 2016-17), and E4 (WZ, 2017-18). Cotton $\left(\mathrm{C}_{6}\right)$ has the highest overall mean among the crops and over the environments. So, it is considered as the crop which is adapted to all the environments.

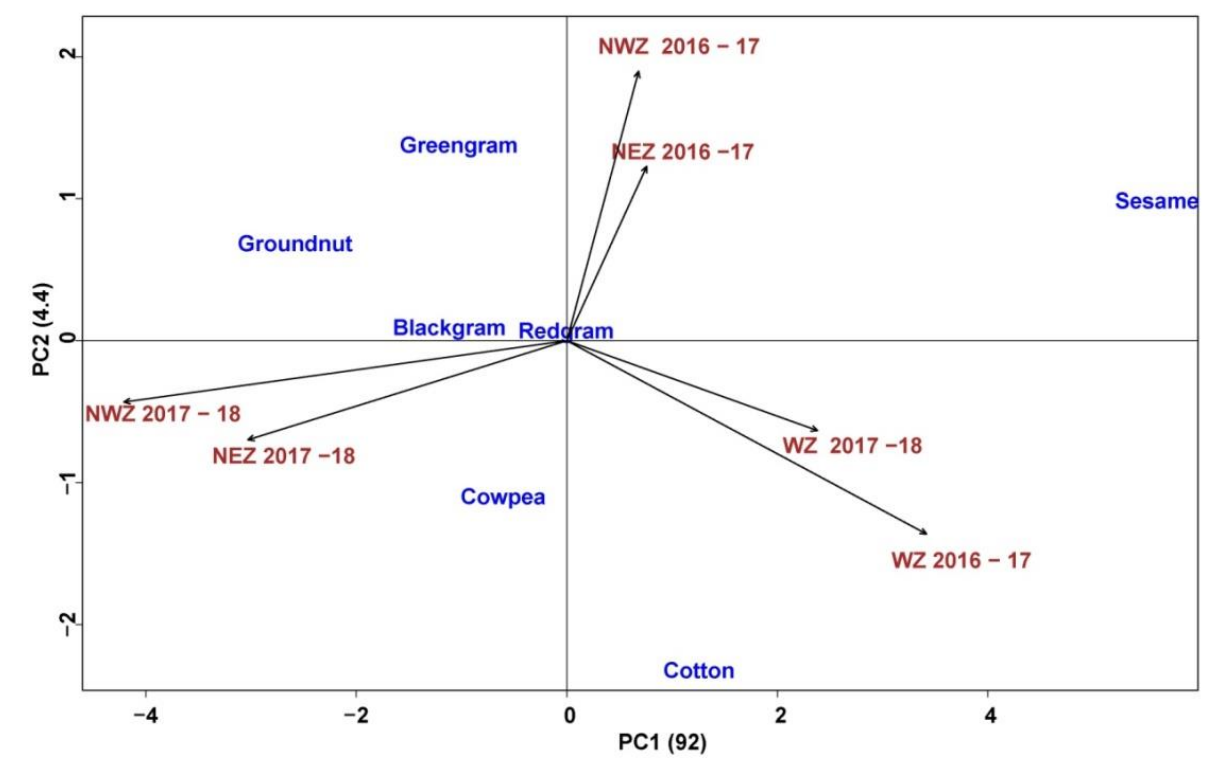

Figure 7. AMMI biplot analysis showing the mega-environments and their respective crops with higher germination

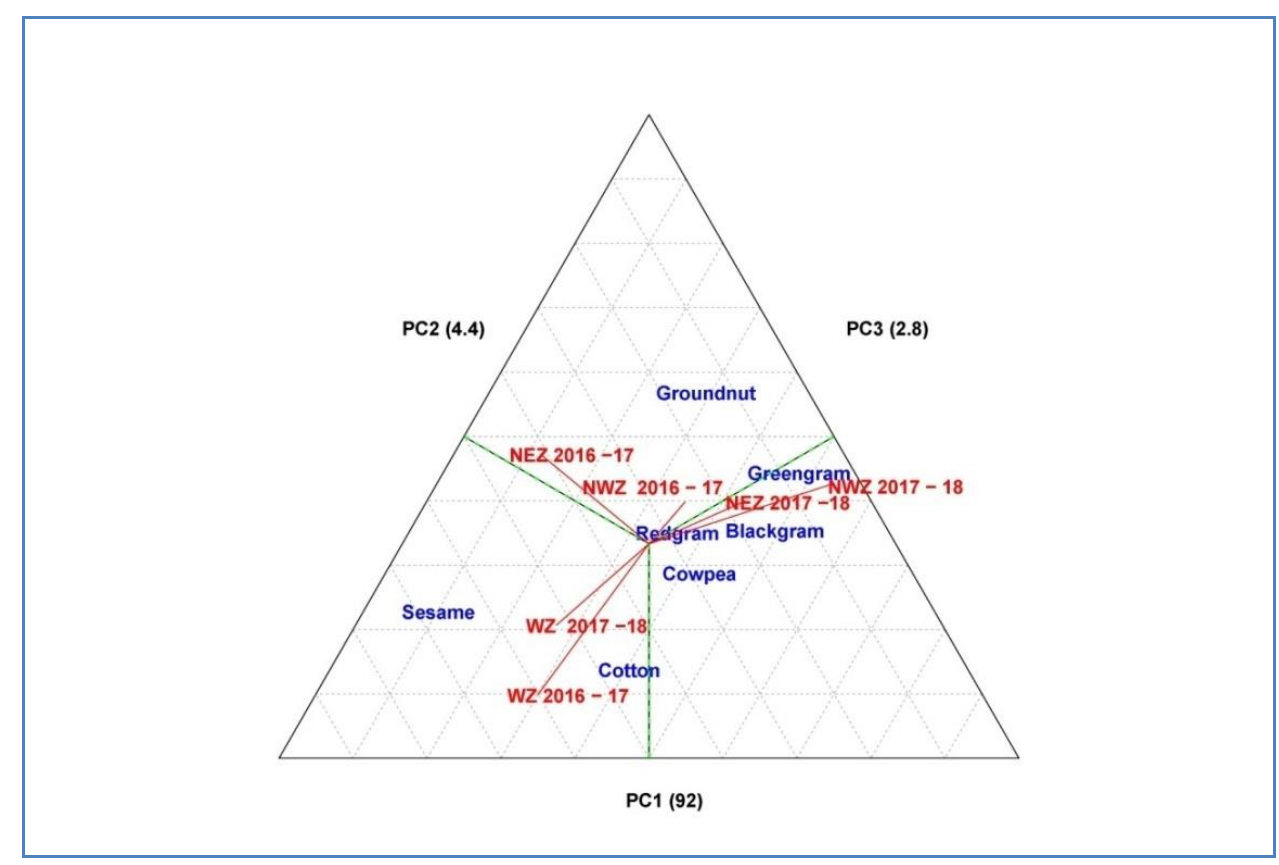

Figure 8. AMMI 1 triplot for germination percentage of test crops and environments using crops and environmental scores 


\section{Conclusion}

From the results and detailed discussion, among the dry sown crops used to cultivate in Northern Tamil Nadu (India), sesame and cotton gave better germination under soil moisture deficit condition and saline soils compared to blackgram, greengram, cowpea and groundnut. These crops (blackgram, greengram, cowpea and groundnut) gave good germination under sufficient soil moisture and salinity free soil condition. Mean time excessive intensive rainfall reduced the germination of sesame under sandy soil condition not in the clay dominated soil. Soil contains higher nutrients (N, P and K), clay encouraged the germination of sesame and cotton, simultaneously reduced the germination of blackgram, greengram, cowpea and groundnut. Over different locations, sesame, cotton and cowpea gave mean higher germination. These crops responded positively to favourable soil and weather condition. Redgram, blackgram, greengram and groundnut gave stable response with poor interaction with environmental condition. Farmers of these zones (WZ, NWZ and NEZ) may be advised to include sesame, cotton and cowpea in cropping system as resilient crop in order to reduce the germination failure with optimum crop stand. These findings strongly recommend to carry out experiments with various field crops like cereals, millets to assess the germination under rainfed sowing. Likewise, investigation on germination of field crops in relation to days interval between rainfed sowing and first receipt of rainfall after sowing is highly needed to dry land farmers to take decision on selecting crops which can survive under aberrant rainfall condition. These findings may directly help farming community to select appropriate crops for dry seeding under rainfed condition.

Acknowledgments. Authors are thankful to former Director of Directorate of Crop Management, Tamil Nadu Agricultural University, who gave permission and helped technically to conduct this extensive study over different research stations situated in Tamil Nadu. Also, authors are grateful for the support given by faculties and farm workers of Regional Research Station, Paiyur; Agricultural Research Station, Virinjipuram and Department of Agronomy, TNAU, Coimbatore.

\section{REFERENCES}

[1] Amini, V., Zaefarian, F., Rezvani, M. (2015): Interspecific variations in seed germination and seedling emergence of three Setaria species. - Brazilian J of Bot 38(3): 539-45. https://doi.org/10.1007/s40415-015-0158-6.

[2] Ashraf, M. P., Harris, P. J. (2004): Potential biochemical indicators of salinity tolerance in plants. - Plant Sci 166(1): 3-16. https://doi.org/10.1016/j.plantsci.2003.10.024.

[3] Ayalew, G. (2015): A geographic information system based physical land suitability evaluation to groundnut and sweet potato in east Amhara, Highlands of Ethiopia. - J of Biol, Agri and Healthcare 5(1).

[4] Basto, S., Dorca-Fornell, C., Thompson, K., Rees, M. (2013): Effect of pH buffer solutions on seed germination of Hypericum pulchrum, Campanula rotundifolia and Scabiosa columbaria. - Seed Sci and Tech 41(2): 298-302. https://doi.org/10.15258/sst.2013.41.2.12.

[5] Benvenuti, S. (2003): Soil texture involvement in germination and emergence of buried weed seeds. - Agron J 95(1): 191-198. https://doi.org/10.2134/agronj2003.1910.

[6] Bewley, J. D., Bradford, K., Hilhorst, H., Nonogaki, H. (2013): Seeds: Physiology of Development, Germination and Dormancy. 3rd Ed. - Springer, New York. 
[7] Bodner, G., Nakhforoosh, A., Kaul, H. P. (2015): Management of crop water under drought: a review. - Agron Sustain Dev 35(2): 401-442. https://doi.org/10.1007/s13593015-0283-4.

[8] Bozso, G., Pal-Molnar, E., Hetenyi, M. (2008): Relations of pH and mineral composition in salt-affected lacustrine profiles. - Cereal Res Commun 36: 1463-6. https://www.jstor.org/stable/90002991.

[9] Dash, M., Panda, S. K. (1988): Salt stress induced changes in growth and enzyme activities in germinating Phaseolus mungo seeds. - Biol Plantarum 44(4): 587-9. https://doi.org/10.1023/A: 1013750905746.

[10] Dinelli, G., Marotti, I., Catizone, P., Bosi, S., Tanveer, A., Abbas, R., Pavlovic, D. (2013): Germination ecology of Ambrosia artemisiifolia L. and Ambrosia trifida L. biotypes suspected of glyphosate resistance. - Open Life Sci 8(3): 286-96. https://doi.org/10.2478/s11535-013-0135-z.

[11] Dove, N. (2010): The Effect of Increasing Temperature on Germination of Native Plant Species in the North Woods Region. - University of Vermont, Burlington, VT.

[12] Durrant, M. J., Mash, S. J. (1989): Stimulation of sugarbeet hypocotyls extension with potassium nitrate. - Annals of App Biol 115: 367-374. https://doi.org/10.1111/j.17447348.1989.tb03395.x.

[13] Erskine, W. (1996): Seed-size effects on lentil (Lens culinaris) yield potential and adaption to temperature and rainfall in West Asia. - J Agric Sci (Camb.) 126: 335-341. https://doi.org/10.1017/S002185960007489X.

[14] Evans, C. E., Etherington, J. R. (1990): The effect of soil water potential on seed germination of some British plants. - New Phytol 115: 539-548. https://doi.org/10.1111/j.1469-8137.1990.tb00482.x.

[15] Eynard. A., Lal, R., Wiebe, K. (2005): Crop response in salt-affected soils. - J of Sust Agri 27(1): 5-50. https://doi.org/10.1300/J064v27n01_03.

[16] Fawusi, M. O., Agboola, A. A. (1980): Soil Moisture requirements for germination of sorghum, millet, tomato, and Celosia 1. - Agron J 72(2): 353-7. https://doi.org/10.2134/agronj1980.00021962007200020023x.

[17] Florentine, S. K., Weller, S., Graz, P. F. (2016): Influence of selected environmental factors on seed germination and seedling survival of the arid zone invasive species tobacco bush (Nicotiana glauca R. Graham). - The Rangeland J 38(4): 417-25. https://doi.org/10.1071/RJ16022.

[18] Gomez, J. M. (2004): Bigger is not always better: conflicting selective pressures on seed size in Quercus ilex. - Evolution 58(1): 71-80. https://doi.org/10.1111/j.00143820.2004.tb01574.x.

[19] Gomez, K. A., Gomez, A. A. (1984): Statistical Procedures for Agricultural Research. 2nd Ed. - John Wiley and Sons, New York.

[20] Hadas, A., Stibbe, E. (1973): Analysis of Water Uptake and Growth Patterns of Seedlings of Four Species Prior to Emergence. - In: Hadas, A. et al. (eds.) Physical Aspects of Soil Water and Salts in Ecosystems. Ecol. Stud. Vol. 4. Springer, Berlin, pp. 97-106. https://doi.org/10.1007/978-3-642-65523-4_11.

[21] Hegarty, T. W. (1976): Effects of fertilizer on the seedling emergence of vegetable crops. - J Sci Fd Agric 27: 962-968. https://doi.org/10.1002/jsfa.2740271014.

[22] Heikal, M. M., Shaddad, M. A., Ahmed, M. (1982): Effect of water stress and gibberellic acid on germination of flax, sesame and onion seeds. - Biologia Plantarum 24(2): 124-9. https://doi.org/10.1007/BF02902858.

[23] Hooftman, D. A., Edwards, B., Bullock, J. M. (2016): Reductions in connectivity and habitat quality drive local extinctions in a plant diversity hotspot. - Ecography 39(6): 583-592. https://doi.org/10.1111/ecog.01503.

[24] Jacobson, M. Z. (1999): Effects of soil moisture on temperatures, winds, and pollutant concentrations in Los Angeles. - J App Meteorol 38(5): 607-616. https://doi.org/10.1175/1520-0450(1999)038<0607:EOSMOT>2.0.CO;2. 
[25] Jepsen, J. K., Henning, R. R., Nyathi, B. (2006): Generative propagation of Jatropha curcas L. on Kalahari sand. - The Jatropha System. https://jatropha.pro/genarativepropagation-of-jatropha-curcas-l-on-kalahari-sand/.

[26] Kaya, M., Kaya, G., Kaya, M. D., Atak, M., Saglam, S. K., Khawar, M., Ciftci, C. Y. (2008): Interaction between seed size and $\mathrm{NaCl}$ on germination and early seedling growth of some Turkish cultivars of chickpea (Cicer arietinum L.). - J of Zhejiang Univ Sci B 9(5): 371. https://doi.org/10.1631/jzus.B0720268.

[27] Keating, B. A., Fisher, M. J. (1985): Comparative tolerance of tropical grain legumes to salinity. - Aust J Agric Res 36: 373-83. https://doi.org/10.1071/AR9850373.

[28] Lamichhane, J. R., Debaeke, P., Steinberg, C., You, M. P., Barbetti, M. J., Aubertot, J. N. (2018): Abiotic and biotic factors affecting crop seed germination and seedling emergence: a conceptual framework. - Plant and Soil 432(1-2): 1-28. https://doi.org/10.1007/s11104-018-3780-9.

[29] Luzuriaga, A. L., Escudero, A., Pérez-Garcia, F. (2006): Environmental maternal effects on seed morphology and germination in Sinapis arvensis (Cruciferae). - Weed Res 46: 163-174. https://doi.org/10.1111/j.1365-3180.2006.00496.x.

[30] Maas, E. V., Hoffman, G. J. (1977): Crop salt tolerance current assessment. - J. of the Irrigation and Drainage Division 103(2): 115-34.

[31] Mendiburu, F., Yaseen, M. (2020): Agricolae: Statistical Procedures for Agricultural Research. $\mathrm{R}$ Package 1.4.0. https://myaseen208.github.io/agricolae/https://cran.r-project.org/package=agricolae.

[32] Michael, A. M. (2009): Irrigation: Theory and Practice, 2nd Edition. - Vikas Publishing House, Noida.

[33] Mohamed, H. A., Clark, J. A., Ong, C. K. (1988): Genotypic differences in the temperature responses of tropical crops: I. Germination characteristics of groundnut (Arachis hypogaea L.) and pearl millet (Pennisetum typhoides S. \& H.). - J. of Exp Bot 39(8): 1121-8. https://doi.org/10.1093/jxb/39.8.1121.

[34] Mucioki, M., Pelletier, B., Johns, T., Muhammad, L. W., Hickey, G. M. (2018): On developing a scale to measure chronic household seed insecurity in semi-arid Kenya and the implications for food security policy. - Food Security 10(3): 571-87. https://doi.org/10.1007/s12571-018-0807-2.

[35] Obroucheva, N. V., Sinkevich, I. A., Lityagina, S. V., Novikova, G. V. (2017): Water relations in germinating seeds. - Russian J of Plant Physiol 64(4): 625-33. https://doi.org/10.1134/S102144371703013X.

[36] Parker, W. C., Noland, T. L., Morneault, A. E. (2006): The effects of seed mass on germination, seedling emergence, and early seedling growth of eastern white pine (Pinus strobus L.). - New Forests 32(1): 33-49. https://doi.org/10.1007/s11056-005-3391-1.

[37] Prasad, R. (2017): Text Book of Field Crop Production: Food Grain Crop. Vol. 1. Indian Council of Agricultural Research, New Delhi. pp. 248-320.

[38] Ramakrishna, A., Tam, H. M., Wani, S. P., Long, T. D. (2006): Effect of mulch on soil temperature, moisture, weed infestation and yield of groundnut in northern Vietnam. Field crops Res 95(2-3): 115-25. https://doi.org/10.1016/j.fcr.2005.01.030.

[39] Rao, P. (2008): Agricultural Meteorology. - PHI Learning, New Delhi.

[40] Salvucci, G. D., Gentine, P. (2013): Emergent relation between surface vapor conductance and relative humidity profiles yields evaporation rates from weather data. Proceedings of the National Academy of Sciences 110(16): 6287-91. https://doi.org/10.1073/pnas.1215844110.

[41] Sarneel, J. M. (2013): The dispersal capacity of vegetative propagules of riparian fen species. - Hydrobiologia 710: 219-225. https://doi.org/10.1007/s10750-012-1022-3.

[42] Saxena, K. B. (2008): World's First CMS Pigeonpea Hybrid Commercialized. ICRISAT, Patancheru.

[43] Saxena, K. B., Mula, M. G., Sugui, F. P., Layaoen, H. L., Domoguen, R. L., Pascua, M. E., Mula, R. P., Dar, W. D., Gowda, C. L. L., Kumar, R. V., et al. (2010): Pigeonpea: A 
Resilient Crop for the Philippine Drylands. Information Bulletin No. 85. - International Crops Research Institute for the Semi-Arid Tropics, Patancheru.

[44] Schillinger, W. F., Schofstoll, S. E., Smith, T. A., Jacobsen, J. A. (2017): Laboratory method to evaluate wheat seedling emergence from deep planting depths. - Agron J 109: 2004-2010. https://doi.org/10.2134/agronj2016.12.0715.

[45] Sehgal, J. L. (1991): Soil-site suitability evaluation for cotton. - Agropedology 1: 49-63.

[46] Shalhevet, J., Reiniger, P., Shimshi, D. (1969): Peanut Response to Uniform and Nonniform Soil Salinity. - Agron J 61: 384-387. https://doi.org/ 10.2134/agronj1969.00021962006100030015x.

[47] Taiyun, W., Viliam, S. (2017): R package "corrplot": Visualization of a Correlation Matrix (Version 0.84). - https://github.com/taiyun/corrplot.

[48] Tang, C., Chen, D. (2017): Interaction between soil moisture and air temperature in the Mississippi River Basin. - J Water Resource Prot 9(10): 1119-1131. https://doi.org/10.4236/jwarp.2017.910073.

[49] Tekiela, D. R., Barney, J. N. (2013): Quantifying Microstegium vimineum seed movement by non-riparian water dispersal using an ultraviolet-marking based recapture method. - PLoS ONE 8(9): e63811. https://doi.org/10.1371/journal.pone.0063811.

[50] Tian, X., Joji, A. (2003): Response of sesame (Sesamum indicum L.) to low oxygen concentration during germination. - Plant Production Sci 6(2): 126-131. https://doi.org/10.1626/pps.6.126.

[51] TN Govt. (2015): Vision (2023), Government of Tamil Nadu. http://www.spc.tn.gov.in/pdfs/TN_Vision_2023.pdf.

[52] Van Rheenen, H. A. (1979): Soil moisture and growth of sesame. - Plant and Soil 53(3): 277-85. https://doi.org/10.1007/BF02277862.

[53] Villalobos, F. J., Orgaz, F., Fereres, E. (2016): Sowing and Planting. - In: Villalobos, F. J., Fereres, E. (eds.) Principles of Agronomy for Sustainable Agriculture. Springer International Publishing, Cham, pp. 217-227.

[54] Wu, G., Du, G. (2007): Germination is related to seed mass in grasses (Poaceae) of the eastern Qinghai-Tibetan Plateau, China. - Nordic J of Bot 25(5-6): 361-5.

[55] Xu, H., Su, W., Di Zhang, L. S. (2017): Influence of environmental factors on Cucumis melo L. var. agrestis Naud. seed germination and seedling emergence. - PLoS ONE 12(6). https://doi.org/10.1016/j.fcr.2005.01.030.

[56] Yousif, Y. H., Bingham, F. T., Yermanos, D. M. (1972): Growth, mineral composition, and seed oil of sesame (Sesamum indicum L.) as affected by NaCl. - Soil Sci Soci of America J 36(3): 450-453. https://doi.org/10.2136/sssaj1972.03615995003600030025x.

[57] Zech-Matterne, V., Tengberg, M., Van Andringa, W. (2015): Sesamum indicum L.(sesame) in 2nd century BC Pompeii, Southwest Italy, and a review of early sesame finds in Asia and Europe. - Vegetation History and Archaeo Bot 24(6): 673-81. https://doi.org/10.1007/s00334-015-0521-3. 